\title{
Towards decolonial human subjects in research on transport
}

\author{
Tim Schwanen \\ Transport Studies Unit \\ School of Geography and the Environment \\ University of Oxford \\ South Parks Road \\ Oxford, OX1 3QY \\ United Kingdom \\ tim.schwanen@ouce.ox.ac.uk
}

\section{Paper prepared for a special issue of \\ Journal of Transport Geography}

on

Decolonial Approaches to Urban Transport Geographies

Final version

17 August 2020

Published as:

Schwanen, T., 2020. Towards decolonial human subjects in research on transport. Journal of Transport Geography 88, 102849. 


\title{
Towards decolonial human subjects in research on transport
}

\begin{abstract}
This article analyses how human subjects are imagined and conceived in research on transport in the analytical and quantitative traditions in Geography and beyond, and outlines several alternative practices of subject formation. It draws on the writings of Sylvia Wynter to argue that, despite long-standing engagement with thinking from the behavioural sciences to diversify economics and engineering oriented understandings of the human subject, analytical/quantitative research on transport remains caught within western-liberal and 'monohumanist' conceptualisations of humanness. These understandings can be dislodged if research concentrates on the transport-related practices and experiences of people who are both inside and outside valorised subject categories and harnesses stories of how people constitute themselves, others and their worlds in and through daily movements. Existing mobilities scholarship, research on brain activity in human-environment interactions, geonarrative methods, and avoiding binary oppositions such as formal/informal transport can all contribute to alternative practices of subject formation in analytical and quantitative transport geography research.
\end{abstract}

Keywords: autopoietic system; decolonial; homo economicus; homo psychologicus; storytelling; Sylvia Wynter 


\section{Introduction}

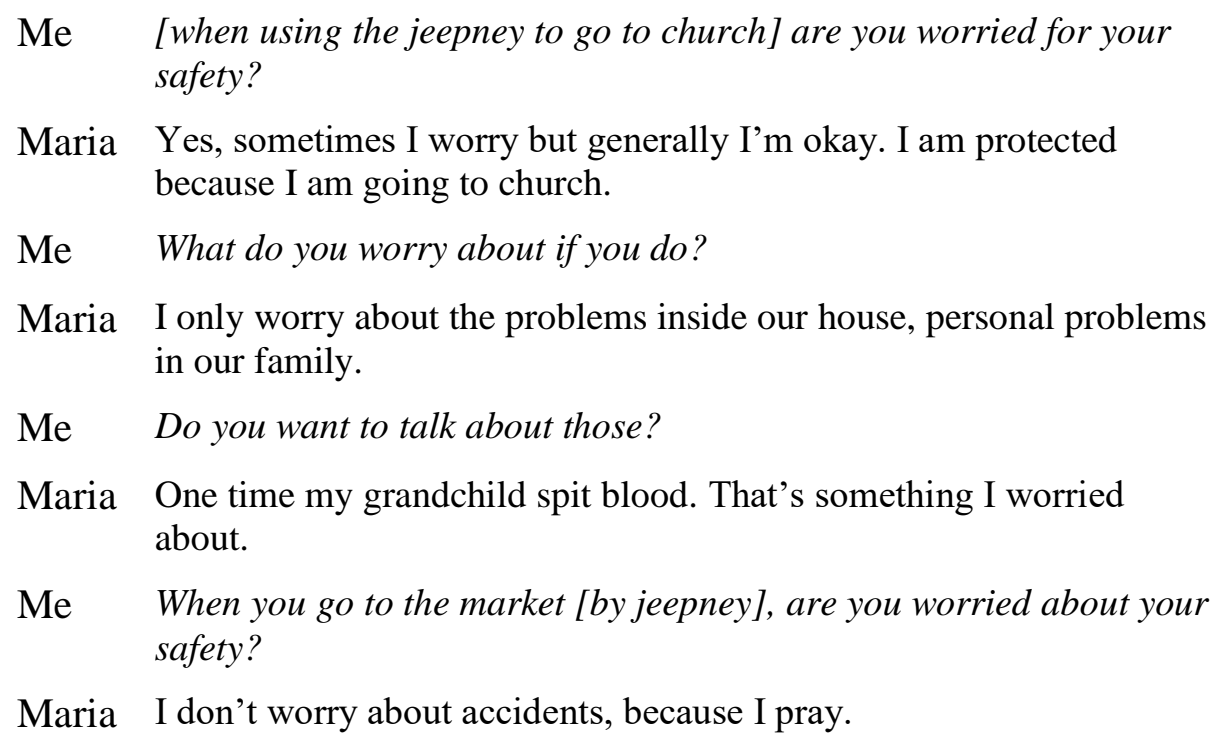

Maria is a grandmother in a semi-formal neighbourhood in central Manila I interviewed with the support of a local interpreter in September 2016. The above excerpt betrays my constitution as a researcher within the hegemonic knowledge traditions of Euro-American transport research and planning. Not only do my questions prolong discourses that equate informality - represented here by Manila's omnipresent minibuses or jeepneys - with inferiority and risk; they also give away my inability to comprehend the significance Maria's religion and religiosity played in shaping her transport practices. Her answers were far from exceptional, as suggested by analysis of the wider set of interviews from which that with Maria was drawn. Monetary factors played a clear role in her transport practices. For Maria, who struggled to get by on the income from street sweeping and selling fruit she gets from the market, the jeepney is eleven times cheaper than the tricycle she sometimes takes from the market back home. It was nonetheless clear that much more was going on, and during and after the interviews with Maria and other older women, it remained difficult to put my finger on how religiosity, experience accrued over their life-course, their social status as elderly 
women, and other elements shaped their experience of being on a jeepney, perception and understanding of risk and protection, and decision-making about how to access places.

My failure to make sense Maria's transport practices and experiences stems at least in part from the grip of that which Sylvia Wynther calls the 'autopoietic system of Man2' (see Section 2.2) on my thinking about choice of transport mode. Transport researchers' concept of 'mode choice' comes with a hinterland of closely related ideas: alternatives; some kind of trade-off or at least comparison; and hence also conditions, (potential) events or cognitions (i.e. perceptions, thoughts) that feature in that trade-off or comparison and somehow mould preferences, intentions or dispositions. In other words, I struggled to 'subjectify' - constitute the people whose practices I examine and try to understand - in a manner that situates Maria in the specific spatiotemporal contexts and situations in which her journeys take place and make sense to her.

Now, the challenge of moving beyond the figure of homo economicus is not limited to me or other individual transport researchers; it is systemic, as the sub-discipline of Transport Geography exemplifies. Multiple commentators have described its conceptual, theoretical and methodological diversity (Keeling, 2007; Schwanen, 2016; Derudder et al., 2019) yet the figure homo economicus continues to loom large, especially if the broad understanding advanced by Sylvia Wynter is deployed. For this, as I will elaborate below, remains the idealtype around which continue to orbit the figure of homo psychologicus which has become very influential in analytical/quantitative transport geography and transport studies more generally. The corollary of this argument is that grounding decolonising/decolonial transport geography research in the seemingly more behaviourally realistic psychologised kin of homo economicus is at best uncomfortable and incoherent. 
The term decolonisation has multiple connotations in relation to academic research. As De Leeuw and Hunt (2018, page 3) explain, it is "far from a fixed concept with clearly delineated practices". Nonetheless, it is often used to denote processes of "interrogating ways that knowledge-making practices marginalise or discount specific people and places, especially by privileging what might be generalised as "western" (often Euro-white) knowledges over "southern" (often racialised) ways of seeing and knowing the world" (ibid.). Decolonising research therefore requires change on multiple levels, including the theories used and developed to make sense of the world, research methods, epistemology and ontology. Critical reflection on, and revision of, how human beings are imagined and assumed to act and think - i.e., how they are constituted as subjects as part of research practices - is an important facet of such change, as numerous post- and decolonial scholars across the social sciences and humanities have shown (e.g. Fanon, 2008[1952]; Wynter, 1984; Danius et al., 1993; Mignolo, 2011).

This article has a dual objective. Building on the writings of Sylvia Wynter, it seeks to analyse how analytical/quantitative transport geography enacts and re-enacts homo economicus or - in Wynter's terms - Man2. It also seeks to chart a pathway forwards, outlining how analytical/quantitative transport geographers can generate new ways of being human or subjectivities in and through their research practices. Below the focus will be in particular on transport geography research in the spatial analysis tradition and in which quantitative methods are dominate. Not only has the figure of homo economicus remained more central to those sectors of the sub-discipline; they have also seen much less influence of post- or decolonial theory than work within, or heavily influenced by, the mobilities turn that has explored questions of colonial history and coloniality ${ }^{1}$ in relation to mobility systems and

\footnotetext{
${ }^{1}$ The historical legacies of Western-European colonialism in Africa, Asia and Latin America and the Caribbean and the continued relevance in the present of social, political and economic hierarchical orderings in the
} 
subject formation (Sheller, 2003, 2009; Clarsen and Veracini, 2012; Clarsen, 2017; Guffin, 2015; Esson et al., 2016; A. Lee, 2015; Mavhunga et al., 2016; Rink, 2016; Bedi, 2017; Evans et al., 2018; Notar et al., 2018; Davidson, 2019). While there is much analytical/quantitative transport geography research that focuses on distributional justice, work in that vein not always engages with the comprehensive conceptualisations of transport/mobility justice which can be found elsewhere in the sub-discipline and in mobilities scholarship and which informs scholarly activism (Cook and Butz, 2015, 2019; Golub et al., 2016; Attoh, 2017; Culver, 2018; D. Lee, 2018; Prytherch, 2018; Sheller, 2018; Enright, 2019). It is through those comprehensive conceptualisations that the links between transport and colonialism, coloniality and racialisation have been examined most fully. A final reason for directing particular attention to analytical/quantitative transport geography is that research of this variety is particularly dominant outside the Euro-American zones of West/North Europe, USA/Canada, Israel and Australia/New Zealand.

In this paper I place the writing by Wynter instead of other post- and decolonial theorists centre-stage because of her radical interdisciplinarity. In her essays she builds on the insights of thinkers across many traditions, including Caribbean philosophy and literature (e.g. Aimé Césaire, Frantz Fanon, Édouard Glissant), post-structuralist philosophy (e.g. Michel Foucault, Jacques Derrida, Judith Butler), Western social sciences (e.g. Gregory Bateson, Immanuel Wallerstein) and the life sciences (e.g. Humberto Maturana, Francisco Varela). She has developed a unique style of subjectification that insists on the importance of understanding humanness as an entanglement of nature (bios, neurochemical processes, the sciences) and culture (mythoi, poetics and storytelling, and the humanities). She also argues that re-thinking subjectification requires a reconfiguring of the broader systems within which people are were originally imposed during Western-European colonisation (Quijano, 2000; Mignolo, 2011). 
constituted as human and knowledge is generated and according to which the world is organised.

The focus on Wynter's work means that the paper inevitably privileges one mode of decolonial/decolonising scholarship, namely that which highlight the need to engage with the work of 'southern' thinkers in a bid to shift the 'geography of reason' and rigid disciplinary boundaries (Maldonado-Torres, 2011). There is thus less engagement with work which emphasises that the primacy of settler colonialist ways of knowing over those of Indigenous people needs to be undone (Asselin and Badile, 2018; de Leeuw and Hunt, 2018).

\section{Re-enacting homo economicus}

\subsection{A brief history}

The claim that analytical/quantitative Transport Geography and the interdiscipline of Transport Studies continue to be centrally configured around homo economicus may seem an exaggeration. Few readers will disagree that this figure remains relevant and a popular choice for practices of subject formation in those research traditions owing to the conceptual flexibility and pragmatic appeal of random utility theory. The subject of neo-classical economic theory who, based on full information, makes optimal choices in cost-benefit tradeoffs continues to animate numerous studies of individual travel/activity choices (e.g. BenAkiva and Lerman, 1985; Bates et al., 2001; Hasnine et al., 2018) and accessibility (e.g., Miller, 1999; Ettema and Timmermans, 2007; Wang et al., 2018). That subjectification is also mobilised and reproduced routinely in empirical studies of trip-making in Africa and South or South-East Asia (e.g. Amoh-Gyimah and Aido, 2013; Lu et al., 2014; Minal and Ravi Sekar, 2016; Agyemang, 2017; Fillone and Babiano, 2018; Acheampong, 2020). But surely the hegemony of homo economicus began to be dislodged in the 1970s? 
One narration of the history of subjectification in transport research indeed suggests that its practitioners have sought to diversify - or rather psychologise - the conceptualisations of human beings and their behaviour from at least the 1970s. Early initiatives engaged with thinking from behavioural psychology on the attitude-behaviour relationship (e.g. Hartgen, 1974; Dobson et al., 1978) and with cross-disciplinary thinking on bounded rationality and learning (e.g. Banister, 1978; Horowitz, 1984). In Transport Geography such developments were part of the broader rise of Behavioural Geography in the 1970s and 1980s and also drew inspiration from the time-geography approach developed by Hägerstrand and colleagues at Lund University, Sweden (e.g. Burnett, 1980; Timmermans, 1983). Hägerstrand's conceptualisation of the human subject moved somewhat towards that of humanistic geography and structuration theory in the 1980s (e.g. Hägerstrand, 1982). Nonetheless, in the 1960s and 1970s - the period in his oeuvre to which transport research tends to reach back his conceptualisation was agnostic to the extent that he did not explicitly consider what human beings might do given the space-time constraints within which they operated. As others have argued (e.g. Giddens, 1984), this is a mode of subject formation that, in its omissions, suggested a pessimistic view on humans' creativity and ability to work with and around space-time constraints.

Arguably, it is since 1990 that psychologised subjectifications of human beings - homo psychologicus - have really proliferated in analytical/quantitative Transport Geography and Transport Studies, with the further incorporation of insights from behavioural psychology, behavioural decision sciences and behavioural economics. Research that capitalised on developments in the understanding of heuristics and learning was/is often positioned as consciously breaking with homo economicus (e.g. Gärling et al., 1998; Arentze and Timmermans, 2003). The same was/is true for research inspired by behavioural economics (e.g. Schwanen and Ettema, 2009; Avineri, 2012). The inclination to do so has perhaps been 
clearest for research that has drawn explicitly on, or sought to extend, theoretical models from behavioural psychology (e.g. Verplanken et al., 1998; Steg, 2005; Chng et al., 2018). Nonetheless, those models and more ad hoc specifications of relevant attitudinal factors have long been cross-fertilised with random-utility theory (e.g. Recker and Golob, 1976), and this process has been normalised with the increased adoption of hybrid choice models (e.g. Walker and Li, 2007; Abotalebi et al., 2019).

Interestingly, and in contrast to other areas of research, Transport Geography and Transport Studies have so far seen little uptake of ideas, logics and methodological practices from the neurosciences. With some exceptions (Cherchi, 2018; Souche-Le Corvec and Zhao, 2020), the ways in which practitioners in those sciences subjectify human beings have as yet have had limited influence on academic transport research.

Nonetheless, the view that drawing on insights from the psychological and neurosciences constitutes a break with the mobilisation and consolidation of homo economicus can be qualified when attention is directed towards Sylvia Wynter's understanding of this figure and its continuing re-enactment.

\subsection{A necessary detour through history}

Part of Sylvia Wynter's intellectual project has been to re-historicise our understanding of human subjectification practices, for which she has elaborated a specific perspective on how knowledge about human beings is generated. Drawing on such a broad project that covers the period since the Middle Ages in Western Europe may seem unnecessary. It is less so when we realise that the thinking of European philosophers and intellectuals on mobility, the notions of Self and Other, community, freedom and race "emerge[d] in the early modern era and over the next few centuries gather[ed] nearly all environments and relations under their ambit" (Seiler, 2016, page 98). 
For Wynter, subject formation occurs within broader autopoietic - self-reproducing and maintaining - systems that benefit particular social groups and interests; her work has sought to elucidate those systems through the development of a wide-ranging historical account (e.g. Wynter, 2003). In so doing, she has explicitly rejected prevailing biocentric accounts of humanness - humans as the most advanced evolutionary being on the planet, best adapted to the habitats in which it functions. She has instead developed Frantz Fanon's (2008[1952]) sociogenic perspective. This recognises that human beings can only become valued as 'human', and thus recognised as belonging to a community of people, if they enact themselves according to certain culturally-specific but also - and here her radical interdisciplinarity becomes evident - neurochemically inflected codes, rules and stories (e.g. McKittrick and Wynter, 2015).

Central to Wynter's history of subject formation are two major transformations in the broader autopoietic systems in which knowledge is generated: the shift from feudalism to capitalism, aided by the Copernican revolution and early European colonialism between \pm 1500 and \pm 1800 A.D, and the rise of industrialisation and imperialism from the late $18^{\text {th }}$ century onwards. The former entailed a secularisation of subject formation and the displacement of a theological conception of human subjects by 'Man1' - the human subject as a rational and political being; the latter triggered a shift towards 'Man2', with humans subjectified as biological and economic beings at the apex of Evolution (e.g. Wynter 2003).

\section{$<$ Table 1>}

As Table 1 highlights, the transformations occur across multiple domains - in no particular order: political economy, religion, science, arts - that shape, stabilise and occasionally disrupt each other. One distinctive aspect of Wynter's historical account is that she credits the Copernican revolution in science with facilitating a homogenisation and universalisation of 
subjectification in which (geographically) differentiated practices were increasingly displaced by a single system that promulgated Man1 on the basis "of the West's liberal monohumanist Man" (Wynter 2015, page 23, emphasis in original). This system not only justified European colonialism and coloniality but also spread across the planet because of them. Moreover, the more recent globalisation of Man2 is, for Wynter, the root cause of the interconnected planetary "poverty-hunger-habitat-energy-trade-population-atmosphere-waste-resource problem" (McKittrick and Wynter, 2015, page 44).

Another key aspect to Wynter's autopoietic systems is the centrality of codes of symbolic death and symbolic life (Wynter, 1984, 2015). These are stories of significant ills or afflictions ('symbolic death' - absence from 'true' being, enslavement) that can be cured or overcome if a particular behavioural pathway is followed ('symbolic life' - 'true' being, cure, freedom). These always culturally specific symbolic codes in turn are closely linked to stories about the origins of humans and human life. For instance, the theological conception of humanness cannot be separated from the Old Testament's Original Sin as symbolic death, whereas natural scarcity of material resources (and at least until the mid-20 ${ }^{\text {th }}$ century "scarcity of fully genetically selected human beings" - Wynter, 2003, page 325) is the symbolic death at the heart of Man2. The ill of scarce resources is to be overcome through market capitalism and rational allocation, which is why Man2 is epitomised in (abstract) subjects that symbolise growth and development, such as the investor and capital accumulator who master and overcome natural scarcity through particular techniques and practices. Together symbolic death/life codes and human origin stories create a 'referentsubject' - and more specifically a 'referent-we' - for a particular society.

Symbolic death/life codes co-evolved historically with political economy and the arts and sciences (Wynter, 2003; see Table 1). Thus, it is the rise of the non-landed bourgeoisie, 
imperialist colonialism and the scientific account of evolution, originally proposed by Darwin (2009[1859]), that are constitutive of Man2. Darwinian theory, in particular, normalised the notion of genetic selection as the basis for hierarchical ordering processes. Yet, the historical evolution of death/life codes is also constrained and dependent on the workings of affect (Thrift, 2008; Bissell, 2010), and specifically "the biochemical reward/punishment mechanism of the brain" (Wynter, 2003, pages 273-274) that are activated by narratives of good and evil in ways that are independent of place, time and culture. The codes are not biological per se but they are implemented neurochemically in a culture-transcending manner.

By promoting a referent-we, the symbolic codes also institute distinctions and exclusions socially and geographically. The creation and neurochemical enforcement of "a self, a we" takes place "through the negation of an Other" (Wynter, 1976, page 79, emphasis in original). In the era of European colonialism this helped to create race as a mode of social ordering, with the black African at the lowest rung. In the era of Man2 this hierarchy was developed further through the institutionalisation of W.E.B. Du Bois' (2007[1903]) colour line between lighter and darker people and claims that black Africans were biogenetically least developed, and barely differentiated from simians in evolutionary terms. Over time, however, hierarchical differentiation was not limited to skin colour, also occurring along the socioeconomic axes of "Rich/Poor, Developed/Underdeveloped and Planet of the surburbs/Planet of the slums" (Wynter, 2015, page 242).

Finally, for Wynter, the autopoietic systems in which the symbolic death/life codes operate are usually opaque - too normalised to be open to reflection to people within those systems. Only when partially outside or on the margins of those systems can one grasp their workings. It is there that one can see that Man2 has shaped, and continues to shape, the lived realities of 
those individuals who do fit in "a morphology that privileges an implicit whiteness, masculinity, cis-ness, hetero-ness, symmetry, and ability" (Parker, 2018, page 440), or live their lives outside the localities favoured by the global circuits of capitalism.

\subsection{Rewriting a history}

Wynter's broad-brush account can easily be criticised, for its universalising tendencies, its glossing over geographical differentiations of historical processes within broad regions such as 'the West' or 'Africa', its disregard for the co-constitution of technology and human beings and their capacities, and for its stark boundary between humans and other organisms (Hantel, 2018; Parker, 2018). Nonetheless, as a narrative exercise it can open up multiple insights about practices of subject formation in Transport Geography and Transport Studies. Most pertinent in the current context is the suggestion that analytical/quantitative research in these fields has only rarely moved beyond homo economicus.

If Wynter is followed, then we can begin to understand the proposition that the homo psychologicus and homo economicus that inhabit transport research are close relatives and in some ways more like twins. This is not simply because psychological factors are integrated into a random utility maximisation framework in many transport studies (see Section 2.1). It is not even primarily because transport studies of behavioural learning tend to be limited to first-order learning ${ }^{2}$ and thus concentrate on how individuals can allocate their (scarce) resources better, or at least adequately, to achieve the transport-related objectives they seek to realise (Horowitz, 1984; Arentze and Timmermans, 2003; Ben-Elia and Shiftan, 2010; Van Essen et al., 2019). In other words, studies of behavioural learning in activity/travel

\footnotetext{
${ }^{2}$ A term coined by Bateson (1972) to denote forms of learning that revolving around achieving a set goal more effectively and efficiently, without critical reflection on that goal per se. Learning to set different and better goals is at the heart of second-order learning.
} 
behaviour tend to adhere to codes of symbolic life that revolve around overcoming situations of scarcity in the trip-making or transport context under consideration.

Instead, the claim that analytical/quantitative transport research has not moved beyond homo economicus reflects that all of the studies referenced in Section 2.1 remain encapsulated in monohumanism and the idea that (quantifiable) growth and development - be this economic or personal - are the ultimate pathways for individuals to secure symbolic life; there is little space for difference and for human beings to be otherwise. The historical links of this mode of subject formation to European colonialism, made explicit via the detour through Wynter's intellectual project above, raise troubling questions about how decolonial/decolonising transport research can and should constitute the human beings whose behaviour it studies, particularly when attention is directed towards people and places that have been, and are, marginalised and disadvantaged by European colonialism and coloniality.

These conclusions also extend to transport research informed by models from behavioural psychology, such as Ajzen's (1991) Theory of Planned Behaviour (TPB). In its basic form this model proposes that an individual's behaviour is the outcome of their intentions which are influenced by their attitudes (subjective evaluations of the behaviour in question), social norms (the views held by relevant others), and perceived behaviour control (subjective beliefs of the extent to which the behaviour can be performed). The theory's psychological constructs are operationalised in empirical research through statements to which participants have to respond.

\section{$<$ Table 2>}

Consider Table 2, the purpose of which is most emphatically not to criticise the work of individual researchers but rather to exemplify and illustrate common practices in a venerable tradition of studying behaviour in transport and other domains. Collectively the listed studies 
demonstrate the efficacy and powerfulness of the TPB for understanding behavioural intentions or motives in the context of urban transport in localities across Africa, Asia and Latin America. All studies are carefully designed and conducted, offering robust econometric analysis and sound conclusions. In keeping with conventions, all use five-point Likert or semantic scales to measure psychological constructs, usefully substituting continua in the form of ordinal measurement scales for the binary oppositions that prevail within the autopoietic system of Man2.

Nonetheless, the use of ordinal measurement scales cannot fully erase Man2's codes of symbolic life and death working in the background: alongside a referent-subject who enjoys pleasure, freedom, independence, convenience, time or cost savings, status, the ability to express their identity and so forth, the research practices behind the studies in Table 2 also enact an Other who is deprived of all those qualities or is poor, traditional, etcetera. In other words, an $U s$ is brought into being, with whom study participants - and certainly me as reader of the published articles - can identify at an embodied-affective (neurochemical) level, through the negation of the Them, from whom those participants - and I - can readily distance them/ourselves.

Although the number of studies in Table 2 is small, they display a recurring pattern in that far fewer items can be mapped directly onto Wynter's category of symbolic death than on symbolic life. It is predominantly through semantic scales that the former category is made explicit (and, as the wider TPB literature attests, Likert scales are used much more than semantic ones). As a result, the creation of (a context-specific) Man2 in the sampled studies is to a large extent implicit and veiled. Moreover, the enacted versions of Man2 are not necessarily linked rigidly to specific behaviours or intentions. The studies by Van et al. (2014) and Le Loo et al. (2015) use items to operationalise psychological constructs which 
enable study participants to enact identities in line with the implied symbolic death/life codes, irrespective of whether they drive or use public transport.

Finally, the studies in Table 2 diverge clearly from Wynter's narration of Man2 as there are no references to race in the measurement of the TPB's psychological constructs - as one would expect for peer-reviewed articles in respected international journals. The papers nonetheless stand in the shadow of history. By mobilising a theoretical framework that is deeply grounded in Euro-American liberal thought, the studies exemplify the much wider praxis of routinely relying on 'western' and 'westernised' expectations, norms and standards to study transport realities in localities across the global South without explicitly problematising their appropriateness.

One objection to the arguments here might be that difference and variation are at the heart of studies such as those in Table 2, and indeed any transport studies inspired by neoclassical or behavioural economics. This is true, but only on one level: difference is here reduced to deviance from given and static categories and remains within the parameters of the only slowly changing autopoietic system of Man2. There is little space for difference that is outside pre-established categories and binaries and that is generative and creative - i.e., difference that in social theory sometimes is referred to 'alterity', philosopher Deleuze (1994[1968]) calls 'difference in itself', and that is also central to Wynter's alternative to Man2 for which she uses the term homo narrans - the sociogenic understanding of the human subject that recognises the central role of story-telling in the constitution of human subjects and the disruption of Man2's dominance (McKittrick and Wynter, 2015).

\section{Subjectifying otherwise: being ecumenically human}


The preceding discussion has proposed that subject formation in analytical/quantitative transport geography and transport studies research operates through what are ultimately binary categories, the nature of which is no longer defined in straightforwardly racial terms and is contingent on place-specific conditions and histories as well as the particularities of the surveys used and the data processing and analysis practices deployed. Nonetheless, the binary categories tend to be rooted in Euro-American liberal thought gone global and prohibit an appreciation of how the actions of transport service users, providers and regulators are different-in-themselves, generative and creative, and ultimately opening up the subject formation practices of homo narrans.

In her work, Wynter has identified multiple ways in which researchers can subjectify in different ways and so help dislodge and displace the homo economicus at the heart of contemporary globalised capitalism and much transport planning and research. Apart from engaging in activism, including anti-colonial participatory action research, scholars and scientists interested in transport (or other topics) can engage in two interrelated research practices:

- Make graspable: focus on the embodied experiences of (im)mobility by liminal subjects to document the marginalisations and exclusions that Man2's autopoietic system creates; and

- Narrativise: Tell different stories that poetically create different subjects, worlds and transport systems, in the process moving beyond binary oppositions and relativising Man2.

Drawing on mobilities research and closely connected transport geography scholarship can aid in the development of these two strategies in work that engages directly ideas, methods and practices of analytical/quantitative research on transport. 


\subsection{Making graspable: focus on liminal subjects}

Recall that, for Wynter, the symbolic codes at the heart of the autopoietic system of Man2 are too opaque and normalised to be grasped fully. This is much easier for those with "the cognitive edge” (Wynter, 1987, page 237) afforded by the 'two-ness' or doubleconsciousness (Du Bois, 2007[1903]; Brand, 2018) that is generated through lived experience of being both in and outside the referent-we. The ambiguity and complexity of such lived experience can trigger internal conflicts and anguish. This is, firstly, because liminal subjects with double consciousness can see themselves simultaneously through the eyes of the referent-we and its Other. Du Bois' notion of double-consciousness was geared towards the experience of blacks in the context of race relations in the early $20^{\text {th }}$-century USA; however, the work of Fanon, Wynter and others suggests that its logic can be broadened to other, intersecting identity categories and to refer to a referent-we that is white, (neo)colonial, masculine, aged, able-bodied, heterosexual, and so forth. The second reason is that those who simultaneously belong to and are excluded from the referent-we will, with some frequency, be in situations where they have to deny and reject their particular being - skin colour, ancestral lineage, transnational background, gender, years since birth, bodily capacities, (carnal) desires, and so forth - in order to fit in with the realities linked to prevailing symbolic death/life codes.

Wynter suggests that lived experiences of double-consciousness are not merely traumaticthough they certainly can be that - but also generative insofar that they can lead to important empirical and conceptual insight. A case in point is Frantz Fanon's biography, for it was a specific set of experiences that enabled him to develop the concept of sociogeny and challenge colonialisms later in his life (see Fanon, 2008[1952]) and later books): while acculturated and assimilated into the French colonisers' symbolic life/death codes during his 
elite education in native Martinique and thus feeling normal in that context, Fanon felt abnormal when he was regularly positioned as a second-class black colonial subject after arriving in France by white people who sensed and - presumably - feared his skin colour. It was this two-ness that fuelled his intellectual endeavours and activism. ${ }^{3}$

Empirical insights about double-consciousness in regards to transport systems have been documented in mobilities and transport research that has used a suite of qualitative methods in multiple geographical contexts. Purifoye (2015) charts the 'nice-nastiness' - White individuals' expressions that mix politeness, disdain and distancing - that Afro-Americans and other ethnic/racial minorities experience on Chicago's public transport. Examples include Whites ignoring their existence, whispering, standing instead of taking a seat, keeping quiet to let ethnic/racial minorities have their auditory space, and exaggerating their confidence when engaging minority passengers. Such micro-behaviours presumably activate and prolong Afro-Americans' and other ethnic/racial minorities' double consciousness, profoundly shaping their affective experience of urban transport and the city more widely. Reed-Musson (2017) explains how Latino and Caribbean migrants in rural Ontario, Canada experience the relative freedom that cycling affords, even if this is in heavily car-dependent localities, whilst also being subjected to racist abuse when cycling and exposed to bicycle training projects that emphasise the need to make themselves better visible - and hence more vulnerable. The notion of atmospheric politics developed by Alderman et al. (2019) against the background of Geography's broader affective turn (Thrift, 2008; Bissell, 2010) is useful in this context. Like rural Ontario's migrant cyclists, older car-driving African-Americans in their study in Knoxville, Tennessee experienced driving a car during the Jim Crow era as both liberating and a source of intense stress given their precarious position "within a white supremacist

\footnotetext{
${ }^{3}$ She also describes the case of Édouard Glissant (Wynter, 1989) and it would seem that the work of numerous black, Africana, postcolonial, LGBT+, differently-abled theorists and/or activists is fuelled to some degree by their specific double consciousness.
} 
order" and exposure to "real instances of intimidation and violence precipitated by hostile White authorities and citizens". Clarsen's (2017) analysis of Aboriginal automobilities in Australia suggests a similar atmospheric politics of in- and exclusion. She describes how, in the early and mid- $20^{\text {th }}$ century, some Aboriginals owned and used cars which "brought pleasures and opportunities but also dangers from unwanted curiosity, threats of violence and arrest", which made them seek "historical silence" (page 528).

Studying the behaviours and experiences of liminal subjects in the context of atmospheric politics is a particularly powerful way for transport geographers to grasp and communicate the myriad ways in which racialised - and simultaneously also gendered, aged, sexualised, and so forth - structures and symbolic death/life codes shape everyday mobility, transport planning, and operational transport systems. And they can do so quantitatively, or at least using mixed-method approaches. Activity-travel diaries and GPS tracking can provide useful insight about the trips and non-movement of individuals whose relationships with the referent-we are ambiguous and potentially shifting, depending on where they are at particular times. These data can be complemented by interviews configured around them (as in Andrade et al.'s [2019] study of sex workers in Tijuana and Ciudad Juárez, Mexico), by data on biomarkers such as skin conductance or brain activity using devices that are worn on diary/tracking days, or by pre-existing data on who is present or lives in the places and territories that the research participants move through (as in Wang et al., 2019).

In all cases, however, it will be essential to adopt collaborative research designs that give research participants an active say in what data is collected, what categorisations are deployed, and which events or encounters are selected as requiring scrutiny. This ethos of coproduction and re-distributing expertise is as appropriate to feminist and more-than-human 
geographies (e.g. Cameron and Gibson, 2005; Lane et al., 2011) as it is to research influenced by Wynter's writings.

Harnessing the possibilities of brain activity research is particularly significant in light of Wynter's propositions outlined in Section 2.2. She has sought to develop Césaire's (1982) 'science of the Word' as a means to institutionalise homo narrans. On Wynter's reading, Césaire advocated knowledge generation practices that examine how discourses (mythoi) condition with nature (bios) in the form of brain activity in order to decentre biocentric approaches to subjectification. Research on the interactions between brain activity and the environment outside the human body has burgeoned in recent decades, and a recent metareview by Norwood et al. (2019, page 8 ) has confirmed that the brain's "limbic system (e.g. hippocampus, amygdala, insula) was more active in uncomfortable urban, and other uncomfortable environments, reflecting more negative emotional stimulation", whereas the "basal ganglia, which tend to be activated in natural environment, were not more active in urban settings". The authors also indicate that these effects are largely independent of the deployed measurement technique (i.e., electroencephalography [EEG], functional magnetic resonance imaging [fMRI], or near-infrared spectroscopy [NIRS]), which is important as these techniques can create divergent results and all demand extensive interpretation on the part of the analysts involved.

Now, recent work on the brain-physical environment nexus is premised on biocentric understandings of the human subject, and partly because of this pays (very) limited attention to exactly who - which individuals or groups of people - are shown in (static) images to study participants (as in e.g. Tang et al., 2017; Kim et al., 2019) or encountered during walking that the participants undertake (see e.g. Aspinall et al., 2015; Lin et al., 2020). Nonetheless, research in this vein could be developed to examine and develop Wynter's ideas 
about sociogeny, and see if and how the coming together of different bodies at different sites, time of day and whether walking, cycling, waiting for a bus, on light-rail, in a car and so forth generates differences in brain activity. This would allow for testing of specific hypotheses around the neurochemical implementation of the codes, rules and stories Wynter has described. Research in this vein can and should consider how automobility and some public transport developments (e.g. metro and BRT systems in certain cities) help to segregate social groups and reduce encounters and mingling between them. The neuroscientific dimensions of these processes remain to be examined.

It is evident that sociogenic research using brain activity monitoring demands careful navigation of the landscape of research ethics, and it may be rather challenging to obtain approval from research ethics boards. Yet, if done reflexively and with participants as fullfledged co-researchers, then the work can provide insight on a wide range of questions, including the constitution of inter-group conviviality and prejudice in hyperdiverse cities (Valentine, 2010; Kraftl et al., 2019), preference for and satisfaction with different modes of transport, and - at a higher level of theoretical abstraction - the workings of the autopoietic system of Man2 in different geographical contexts across the global North and South.

Research in this vein has merit for another reason. Using the measurement of brain activity and other biomarkers to examine sociogeny within transport configurations will help researchers to overcome the problematic binary between science and the arts/poetry, or quantity and quality, that underpins Césaire's (1982) 'science of the Word'. He started from the premise that, unlike the arts/poetry, the sciences generate "impoverished" (ibid., page 18) knowledges, implying that the contribution that the latter can make to the dislodging of biocentric versions of subjectification is ultimately limited. By placing much more significance on neurochemical brain activity, Wynter begins to move beyond the common 
'bifurcation' of reality into two domains (cf. Whitehead, 1920) that Césaire also reproduces. The first of these domain is the 'objective' realm of bodies, movements from A to B and brain activity - still widely seen as the proper focus of the (positivist) sciences. Then there is the secondary, 'subjective' realm of the mind and culture, which includes sensations, perceptions, beliefs, interpretations, and so forth, and which is often associated with the humanities.

Wynter's version of sociogeny rejects the separation of the primary from the secondary realm, and the privileging of one over the other, and arguments that the humanities are superior to the sciences - as put forward by Césaire and numerous others, including most humanities scholars inspired by Wynter - or the reverse position (which those trained in 'positivist' traditions are more likely to inhabit). Wynter's sociogenic approach is animated by radical interdisciplinarity: she does not take the position that the 'hard' behavioural sciences "substitut[e] ... cold facts" for the polyvalent experiences of human subjects but rather allows those sciences "to look for what in the [subject] responds when interrogating in another way (Latour, 2005, page 231).

With regards to transport and mobility, Wynter's approach allows for a rapprochement between analytical/quantitative transport geography research, in which digital data and thinking on complex systems ${ }^{4}$ have become widely used, on one hand and thinking on inequality, subject formation and embodiment in mobilities scholarship on the other. This in turn offers an opportunity to avoid further fragmentation in Transportation Geography, where the desire to engage with developments in both mobilities research and data sciences is pulling the sub-discipline in different directions (Schwanen, 2016, 2017).

\footnotetext{
${ }^{4}$ Varela and Maturana's (1991) work on autopoiesis offers one version of this.
} 


\subsection{Narrativising: cultivating homo narrans through different stories}

Research on transport inspired by Wynter should not be limited to raising awareness about existing symbolic death/life codes and their effects on mobility. Just as important is to move beyond those, and Wynter's proposal is to encourage particular forms of autopoiesis that foster homo narrans: if, as Fanon (2008[1952], page 179, emphasis in original) argues, "the real leap consists in introducing invention into existence" and "[i]n the world through which I travel, I am endlessly creating myself", then story-telling is crucial to how people as individuals and collectives fashion themselves and how they are subjectified by others (including academic researchers). Thus, Wynter urges modes of story-telling that institute an anti-colonial - and also: non-racialised, non-gendered, post-capitalist, and so forth - referentwe and generate a truly planetary, inclusive and ecumenical humankind and belonging.

The challenge of cultivating homo narrans is monumental and clearly transcends any single research field, academic discipline and indeed mode of knowledge generation (the sciences, literature, visual arts, etc.). Yet, there are many useful examples of research in areas close to Transport Geography that can help inform research into how humans constitute themselves, others and their worlds in and through daily trip-making. Further to experimentation with story-telling in Cultural Geography (e.g. Cameron, 2012; Zonn, 2020), there are many studies in mobilities research that have used story-telling techniques. These include FreudendalPedersen's (2007) structural stories ${ }^{5}$ as well as oral histories (Alderman et al., 2019), autoethnography (Rink, 2016), archives (Clarsen, 2017) and photo elicitation (Cook and Butz, 2015).

Qualitative methods are well suited to story-telling in ways that avoid Man2-style subject formation, but the use of quantitative data and methods is certainly not precluded. Mixed-

\footnotetext{
${ }^{5}$ These explain the rationalities behind people's actions and daily routines and render their views on certain problems and associated solutions understandable (Freudendal-Pedersen, 2007, page 29).
} 
method approach can offer particularly powerful and effective modes of story-telling, as exemplified by the geo-narrative approach developed by Kwan and colleagues (Kwan and Ding, 2008; Andrade et al., 2019; see also Mennis et al., 2013; Battista and Manaugh, 2017; Bell et al., 2017). However, even with purely quantitative research can different stories be told, although the emphasis will shift: it is first and foremost the researchers who need to tell different stories, for instance by using flexible theoretical frameworks of behaviour that avoid the monohumanism and symbolic death/life codes of Man2's autopoietic system. So there would need to be extensive space for difference and differentiations in the representation and interpretation of (changes in) human action.

Irrespective of what data and research methods are used, the cultivation of homo narrans in transport research will be facilitated by moving beyond binary oppositions that create sociospatial hierarchies in, and through, transport. One such binary, which is particularly pertinent to subject formation practices related to transport beyond the global North, is the informal/formal transport binary.

\subsubsection{Beyond informal transport}

On one level, informal transport is a useful category, widely used to denote transport services that are offered often, though by no means exclusively, ${ }^{6}$ in developing countries as an entrepreneurial response to a lack of fiscal and institutional capacity (Shimazaki and Rahman, 1996; Cervero and Golub, 2007; Behrens et al., 2016). Moreover, low costs and flexibility in the sense of adaptability to changing markets and responsiveness to passenger demands are widely seen as benefits of this kind of service provision. It nevertheless seems that these benefits are often exceeded by significant disadvantages, such as erratic service provision,

\footnotetext{
${ }^{6}$ See, for instance, research on Uber and Central Asia's minibuses called mashrutkas (Sgibnev and Vozyanov, 2016; Rekhviashvili and Sgibnev, 2018) and on dollar cabs in Brooklyn New York (Best, 2016; Goldwyn, in press).
} 
lack of capacity and investment, evasion of taxes and fees, inefficient business practices, worker exploitation (ibid.). Unsafe conditions for customers in terms of enhanced risk of traffic injury as well as sexual harassment are another quality often associated with informal transport services (Kash, 2019).

On another level, the category of informal transport is fundamentally problematic: in binary opposition to formal transport services, the term may generate in planners, regulators, and possibly service users, providers and researchers, the neurochemical implementation of what Wynter understands as symbolic death - a sense that informal transport is an inferior option that is condoned, used and offered in the absence of a somehow better alternative.

Consequently, both providers and users of those services risk being subjectified in specific ways - as backward, undisciplined, poor, vulnerable and unsuccessful, even though there usually is large heterogeneity in the lived experience of the people who run and use the services.

This autopoietic configuration of collective meanings, neurochemical processes in individuals and embodied practices seems to have triggered at least four common consequences, although their specific manifestation may be geographically differentiated. First, a lack of care for each other, the vehicles used and supporting infrastructures (routes, stops, safety standards, etc.) may have been induced and consolidated among many of the service providers and customers. ${ }^{7}$

Second, despite taking many different forms in practice, interventions in informal transport by planners and regulators tend to follow the template of the western(ised) and formal(ised) opposite and resonate with the symbolic life codes of Man2. Thos interventions thus hope to

\footnotetext{
${ }^{7}$ Of course, this will not apply to everybody and everywhere: in those places and for those people where the alternative is no (mechanised) transport service whatsoever and/or livelihoods outside working as a driver or fare collector are difficult to access, informal transport services can obtain the qualities of Wynter's symbolic life, activate individuals' neurochemical reward systems, and induce forms of care and positive commitment.
} 
achieve greater efficiency, speed, standardisation, and predictability; contribute to economic development and customer satisfaction; and reduce pollution and traffic injury via (e.g. Behrens et al., 2016; Schalekamp, 2017; Hasan and Dávila, 2018):

- Incremental improvements in technical operation - e.g. vehicle safety, driving styles, ownership, competition, and labour relationships;

- Gradual enhancement of the capabilities of current drivers, owners and (local) policymakers to change established practices of service provision, for instance with the aid of GPS tracking or training in entrepreneurship;

- More abrupt and systemic disruption through blanket or place-specific (e.g. city-centre) bans on operation, or the creation of new formal transport systems, such as Bus Rapid Transit into which informal services are supposed to assimilate.

Third, alongside these efforts to remake the materiality the informal transport systems, there have been attempts by professionals and academics to discursively reposition and revalorise such systems. Consider as an example from the academic literature Woolf and Joubert's (2013, page 284, emphasis added) claims that "[m]inibus paratransit provides key opportunities in development" and "if approached correctly, paratransit is more likely to be part of the land use and transport solution, and not a problem as it is often perceived to be". In a similar vein, multiple studies have suggested that informal services such as motor taxis in Sub-Saharan Africa have extended motorised transport to groups whose mobility needs are not satisfied by formal public transport systems (e.g. Diaz Olvera et al., 2012; Ehebrecht et al., 2018; Evans et al., 2018). From Wynter's perspective, these endeavours can be understood as attempts to reconfigure the neurochemical motivating/demotivating systems in the brains of transport planners and other professionals and to assemble an atmospheric politics that is conducive to supportive forms of (policy) intervention around informal transport services. 
Fourth, and particularly productive in light of the article's earlier sections, are those responses that seek to unsettle the informal/formal opposition through story-telling. Thus, by focusing on processes of informalisation, Rekhiashvili and Sgibnev (2018) analyse Uber one of the darlings of the hyper-capitalist platform economy - as a form of informal transport service. Heinrichs et al. (2018, page 149) take a different tack, arguing on the basis of an analysis of Dar es Salaam's public transport system that it is "unrealistic ... to draw a clear distinction between formal and informal spheres as observers of the 'informal sector' often do". This is because "[s]uch a dichotomy does not reflect adequately the various and often intangible forms of co-existence, merging and application of state regulation and of (implicit) rules and practices which stem from established and changing social norms, experiences or traditions". Equally illuminating in this regard is Goldwyn's (in press) comparative study of dollar vans and 'formal' buses in Brooklyn, New York which suggests that there is hardly a qualitative difference in how dollar van drivers and New York's Metropolitan Transportation Authority set up new routes for bus services.

Nonetheless, it is Best (2016) and Xiao (2019) who take this strand of research furthest by telling stories about subject formation. The former moves understandings of the predominantly Caribbean drivers of Brooklyn's dollar cabs “past the opportunistic immigrant narrative" (Best, 2016, page 444), whilst also foregrounding how - contra Man2 - speed is a sign of recklessness and irrationality. Xiao (2019), for his part, shows by rhythmanalysing Lagos' public transport systems that the formal-informal dichotomy sheds little light on how passengers improvise not only transport spaces but also subjectivities consensually with each other, and also with drivers and policymakers.

At the same time, the above studies tend to remain somehow within the formal/informal binary opposition, or use close alternatives to the latter term in the pair, such as paratransit, 
indigenous transport, or - in Francophone Africa - artisanal transport (Rimmer, 1984; Behrens et al., 2016; Mateo-Babiano, 2016). Particularly outside the global North any of these terms risk reproducing the symbolism that is commonly associated with the formal/informal transport binary. ${ }^{8}$ In all instances the legal, rational, hierarchically ordered transport systems associated with the Western world are likely to remain the 'silent referent' (Chakrabarty, 2000) against which they are compared, with due consequences for subject formation. The implication is that moving beyond the formal/informal transport binary opposition entails abandoning synonyms for one or both terms. The preferable option is to simply refer to the transport mode or technology used (minibus, motor bike taxi, etc.) or refer to the organisation for which they offer services or by which they are run (company name, syndicate name, independently operated, etc.).

\section{Conclusion}

Through engagement with Sylvia Wynter's writings, the article has offered but one pathway for decolonising/decolonial transport geography research which complements a wide array of earlier work on mobilities and transport. The course charted here is inevitably limited and full of contradictions. This is not least because privileging Wynter and the thinkers who have influenced her most, all of whose texts are widely available in English, risks marginalising the important contributions that the work of numerous other post- and decolonial thinkers can make to changing the research practices of analytical/quantitative transport geography. More experimentation with their work, with Indigenous ways of knowing and with researcheractivists seeking to achieve greater transport/mobility justice for different racial/ethnic groups

\footnotetext{
${ }^{8}$ This is even true of paratransit, a term that was originally coined to describe demand-responsive public transport services for specific users groups (e.g. elderly) in rural and suburban North America in the 1960s (Rimmer, 1984).
} 
(see e.g. www.untokening.org) is urgently required. Where possible, this should be led by researchers outside privileged 'Northern' institutions.

At the same time, the article has demonstrated the potential of studying the geographies of transport with Wynter. Her work complicates, slows down and disrupts how transport geographers and researchers imagine and constitute the human beings whose transport-related behaviours, practices, motivations, concerns and experiences we study. It relativises the differences between economically and psychologically oriented understandings of human behaviour, makes us aware of the shadows that history casts over the present use of those understandings, and challenges their supposed universality. It also offers new concepts and methodological practices, as the above discussions of sociogeny, double consciousness and story-telling have indicated.

Thinking with Wynter, I am also equipped to return to the interview with Maria. The story of her mobility foregrounds the significance of the monetary cost of transport, but if that story is refracted through the lenses afforded by the autopoietic system Man2, we risk overprivileging cost factors, poverty and safety risks at the expense of other elements. If we bracket those systems as much as possible, avoid binary oppositions and understand her as a homo narrans, then we also see a story about an embodied attunement to the world around her during mobility. This is an attunement that is cultivated through practices of praying and hinges on the deep entanglement of God's agency and the dynamic world of active bodies, technological artefacts, physical infrastructure, conventions, desires, affective forces, etcetera of which she is part. Consequently, this is also an attunement that prolongs a history of colonialism - not least because the Spanish brought Catholicism to the Philippines in the $16^{\text {th }}$ century - and much else. A fascinating research agenda is opening up here - to be addressed with all methods transport geographers have in their repertoire - about how place-specific yet 
always networked colonial and post-colonial histories continue to shape and mould the dynamics of contemporary transport systems and practices.

\section{References}

Abotalebi, E., Scott, D.M., Ferguson, M.R., 2019. Why is electric vehicle uptake so low in Atlantic Canada? A comparison to leading adoption provinces. Journal of Transport Geography 74, 289-298.

Acheampong, R.A., 2020. Spatial structure, intra-urban commuting patterns and travel mode choice: Analyses of relationships in the Kumasi Metropolis, Ghana. Cities 96, 102432.

Acheampong, R.A., 2017. Towards sustainable urban transportation in Ghana: exploring adults' intention to adopt cycling to work using theory of planned behaviour and structural equation modelling. Transportation in Developing Economies 3, 18.

Agyemang, E., 2017. Mode choice for long distance trips: Evidence from the Greater Accra Metropolitan Area of Ghana. Journal of Transport Geography 64, 150-157.

Ajzen, I., 1991. The theory of planned behavior. Organizational Behavior and Human Decision Processes 50(2), 179-211.

Alderman, D., Williams, K., Bottone, E., 2019. Jim Crow journey stories: African American driving as emotional labor. Tourism Geographies, DOI: 10.1080/14616688.2019.1630671.

Amoh-Gyimah, R., Aido, E.N., 2013. Mode of transport to work by government metropolis in the Kumasi metropolis, Ghana. Journal of Transport Geography 31, 35-43.

Andrade, E., Leyva, R., Kwan, MN.-P., et al., 2019. Women in sex work and the risk environment: agency, risk perception, and management in the sex work environments of two Mexico-U.S. border cities. Sexuality Research and Social Policy 16, 317-328.

Arentze, T., Timmermans, H., 2003. Modeling learning and adaptation processes in activitytravel choice: a framework and numerical experiment. Transportation 30(1), 37-62.

Asselin, H., Basile, S., 2018. Concrete ways to decolonize research. ACME: An International Journal for Critical Geographies 17 (3), 643-50.

Aspinall, P., Mavros, P., Coyne, R., Roe, J., 2015. The urban brain: analysing outdoor physical activity with mobile EEG. British Journal Sports and Medicine 49, 272-276.

Attoh, K., 2017. Public transportation and the idiocy of urban life. Urban Studies 54(1), 196213.

Avineri, E., 2012. On the use and potential of behavioural economics from the perspective of transport and climate change. Journal of Transport Geography 24, 512-521. 
Banister, D., 1978. The influence of habit formation on modal choice - a heuristic model. Transportation 7(1), 5-33.

Bates, J., Polak, J., Jones, P., Cook, A. 2001. The valuation of reliability for personal travel. Transportation Research Part E: Logistics and Transportation Review 37(2-3), 191-229.

Bateson, G., 1972. Steps to an Ecology of Mind. Chandler, San Francisco, CA.

Battista, G.A., Manaugh, K., 2017. Using embodied videos of walking interviews in walkability assessment. Transportation Research Record 2661, 12-18.

Bedi, T., 2017. Histories of transport labor, modes of circulation, and mobile subjects in South Asia. Mobility in History 8, 97-106.

Behrens, R., McCormick, D., Mfinanga, D., eds., 2015. Paratransit in African Cities: Operations, Regulation and Reform. Routledge, London.

Bell, S.L., Wheeler, B.W., Phoenix, C., 2017. Using geonarratives to explore the diverse temporalities of therapeutic landscapes: perspectives from "green" and "blue" settings. Annals of the Association of American Geographers 107(1), 93-108.

Ben-Elia, E., Shiftan, Y., 2010. Which road do I take? A learning-based model of routechoice behavior with real-time information. Transport Research Part A: Policy and Practice 44 (4): 249-264.

Belgiawan, P.F., Schmöcker, J.-D., Abou-Zeid, M., et al., 2017. Modelling social norms: case study of students' car purchase intentions. Travel Behaviour and Society 7, 12-25.

Ben-Akiva, M., Lerman, S., 1985. Discrete Choice Analysis: Theory and Application to Travel Demand. The MIT Press, Cambridge, MA.

Best, A., 2016. The way they blow the horn: Caribbean dollar cabs and subaltern mobilities. Annals of the American Association of Geographers 106(2), 442-449.

Bissell, D., 2010. Passenger mobilities: affective atmospheres and the sociality of public transport. Environment and Planning D: Society and Space 28(2), 270-289.

Brand, A.L., 2018. The duality of space: the built world of Du Bois' double-consciousness. Environment and Planning D: Society and Space 36(1), 3-22.

Burnett, P., 1980. Spatial constraints-oriented modelling as an alternative approach to movement, microeconomic theory, and urban policy. Urban Geography 1(1), 53-67.

Cameron, E., 2012. New geographies of story and storytelling. Progress in Human Geography 36(5), 573-592.

Cameron, J., Gibson, K., 2005. Participatory action research in a poststructuralist vein. Geoforum 36(3), 315-331.

Césaire, A., 1982. Poetry and knowledge. Sulfur 5, 17-32. 
Cervero, R., Golub, A., 2007. Informal transport: a global perspective. Transport Policy 14, 445-457.

Chakrabarty D (2000) Provincializing Europe: Postcolonial Thought and Historical Difference. Princeton University Press, Princeton, NJ.

Cherchi, E., 2018. Using eye track devices to understand individual decisions process in stated preferences experiments: an application to the choice of electric vehicles. Transportation Research Procedia 32, 454-463.

Chng, S., Abraham, C., White, M.P., et al., 2018. Psychological theories of car use: an integrative review and conceptual framework. Journal of Environmental Psychology 55, 23-33.

Clarsen, G., 2017. 'Australia - drive it like you stole it': automobility as a medium of communication in settler colonial Australia. Mobilities 14(4), 520-533.

Clarsen, G., Veracini, L., 2012. Settler colonial automobilities: a distinct constellation of automobile cultures? History Compass 10(12), 889-900.

Cook, N., Butz, D., 2015. Mobility justice in the context of disaster. Mobilities 11(3), 400419.

Cook, N., Butz, D., eds., 2019. Mobilities, Mobility Justice and Social Justice. Routledge, London.

Culver, G., 2018. Death and the car: on (auto)mobility, violence, and injustice. ACME: an International E-Journal for Critical Geographies 17(1), 144-170.

Danius, S., Jonsson, S., Spivak, G.C., 1993. An interview with Gayatri Chakravorty Spivak. boundary 2 20(2), 24-50.

Davidson, A.C., in press. Radical mobilities. Progress in Human Geography DOI: 10.1177/0309132519899472.

Darwin, C., 2009[1859]. The Origin of Species: 150th Anniversary Edition. Bridge-Logos, Alachua, FL.

de Leeuw, S., Hunt, S., 2018. Unsettling decolonizing geographies. Geography Compass 12, e12376.

Deleuze, G., 1994[1968]. Difference and Repetition. New York: Columbia University Press.

Derudder, B., Liu, X., Hong, S., et al., 2019. The shifting position of the Journal of Transport Geography in 'transport geography research': a bibliometric analysis. Journal of Transport Geography 81, 102538

Diaz Olvera, L., Plat, D., Pochet, P., et al., 2012. Motorbike taxis in the "transport crisis" of West and Central African cities. EchoGéo 20.

Dobson, R., Dunbar, F., Smith, C.J., et al., 1978. Structural models for the analysis of traveler attitude-behavior relationships. Transportation 7(4), 351-363. 
Du Bois, W.E.B., 2007[1903]. The Souls of Black Folk. Oxford University Press, Oxford.

Ehebrecht, D., Heinrichs, D., Lenz. B., 2018. Motorcycle-taxis in sub-Saharan Africa: current knowledge, implications for the debate on "informal" transport and research needs. Journal of Transport Geography 69, 242-256.

Enright, T., 2019. Transit justice as spatial justice: learning from activists. Mobilities 14(5), 665-680.

Esson, J., Gough, K.V., Simon, D., et al., 2016. Livelihoods in motion: Linking transport, mobility and income-generating activities. Journal of Transport Geography 55, 82-88.

Ettema, D., Timmermans, H., 2007. Space-time accessibility under conditions of uncertain travel times: theory and numerical simulations. Geographical Analysis 39(2), 217-240.

Evans, J., O’Brien, J., Ng, B.C., 2018. Towards a geography of informal transport: Mobility, infrastructure and urban sustainability from the back of a motorbike. Transactions of the Institute of British Geographers 43(8), 674-688.

Fanon, F., 2008[1952]. Black Skin, White Masks. Pluto Press, London

Fillone, A.M., Mateo-Babiano, I., 2018. Do I walk or ride the rickshaw? Examining the factors affecting first- and last-mile trip options in the historic district of Manila (Philippines). Journal of Transport and Land Use 11(1), 237-254.

Freudendal-Pedersen, M., 2007. Mobility, motility and freedom: the structural story as analytical tool for understanding the interconnection.. Swiss Journal of Sociology 33(1), 27-41.

Gärling, T., Laitila, T., Westin, K., eds., 1998. Theoretical Foundations of Travel Choice Modeling. Elsevier, Amsterdam.

Giddens, A., 1984. The Constitution of Society: Outline of A Theory of Structuration. Berkeley, CA: University of California Press.

Golub, A., Hoffman, M. L., Lugo, A.E., Sandoval, G.F., eds., 2016. Bicycle Justice and Urban Transformation: Biking for All? Routledge, London.

Goldwyn, R., in press. Anatomy of a new dollar van route: informal transport and planning in New York City. Journal of Transport Geography DOI: 10.1016/j.jtrangeo.2018.08.019.

Guffin, B., 2015. Concrete politics and subversive drivers on the roads of Hyderabad, India. In: Cidell, J., Prytherch, D., eds. Transport, Mobility, and the Production of Urban Space. Routledge, New York, pp. 64-80.

Hägerstrand, T., 1982. Diorama, path and project. Tijdschrift voor Economische en Sociale Geografie 73(6), 323-339.

Hantel, M., 2018. What is it like to be a human?: Sylvia Wynter on autopoiesis. philoSOPHIA 8(1), 61-79. 
Hartgen, D.T., 1974. Attitudinal and situational variables influencing urban mode choice: some empirical findings. Transportation 3(4), 377-392.

Hasan, M.M.U., Dávila. J.D., 2018. The politics of (im)mobility: rickshaw bans in Dhaka, Bangladesh. Journal of Transport Geography 70, 246-255.

Hasnine, M.S., Lin, T.Y., Weiss, A., Habib, K.N., 2018. Determinants of travel mode choices of post-secondary students in a large metropolitan area: The case of the city of Toronto. Journal of Transport Geography 70, 161-171.

Heinrichs, D., Ehebrecht, D., Lenz. B., 2018. Moving beyond informality? Theory and reality of public transport in urban Africa. In: Lucas, K., Uteng, T.P., eds. Urban Mobilities in the Global South, pp. 34-154. Routledge, London. Horowitz, J.L, 1984. The stability of stochastic equilibrium in a two-link transportation network. Transportation Research $B$ $18,13-28$.

Kash, G., 2019. Always on the defensive: the effects of transit sexual assault on travel behaviour and experience in Colombia and Bolivia. Journal of Transport and Health 13, 234-246.

Keeling, D.J., 2007. Transportation geography: new directions on well-worn trails. Progress in Human Geography 31(2), 217-225.

Kim, M., Cheon, S., Kang, Y., 2019. Use of electroencephalography (EEG) for the analysis of emotional perception and fear to nightscapes. Sustainability 11(1), 233.

Kraftl, P., Bolt, G., Van Kempen, R., 2019. Hyper-diversity in/and geographies of childhood and youth. Social \& Cultural Geography 20(9), 1189-1197.

Kwan, M.-P., Ding, G. (2008) Geo-narrative: extending geographic information systems for narrative analysis in qualitative and mixed-method research. The Professional Geographer 60(4), 443-465.

Lane, S.N., Odoni, N., Landström, C., et al.., 2011. Doing flood risk science differently: an experiment in radical scientific method. Transactions of the Institute of British Geographers 36(1), 15-36.

Latour, B., 2005. What is given in experience? boundary 2 32(1), 224-237.

Le Loo, L.Y., Corcoran, J., Mateo-Babiano, D., Zahnow, R., 2015. Transport mode choice in South East Asia: Investigating the relationship between transport users' perception and travel behaviour in Johor Bahru, Malaysia. Journal of Transport Geography 46, 99-11.

Lee, A., 2015. Place-making, mobility, and identity: the politics and poetics of urban mass transit systems in Taiwan. In: Cidell, J., Prytherch, D., eds. Transport, Mobility, and the Production of Urban Space. Routledge, New York, pp. 153-171.

Lee, D.J, 2018. Delivering Justice: Food Delivery Cyclists in New York City. PhD thesis, City University of New York, available at: https://academicworks.cuny.edu/gc_etds/2794/ (last accessed: 24/05/2020). 
Lin, W. (2016). Re-assembling (aero)mobilities: perspectives beyond the West. Mobilities 11(1), 49-65.

Lin, W., Chen, Q., Jiang, M., et al., 2020. Sitting or walking? Analyzing the neural emotional indicators of urban green space behavior with mobile EEG. Journal of Urban Health 97:191-203.

Lu, Q.-A., Zhang, J., Peng, Z.-R., et al., 2014. Inter-city travel behaviour adaptation to extreme weather events. Journal of Transport Geography 41, 148-153.

Maldonado,Torres, N., 2011. Thinking through the decolonial turn: post-continental interventions in theory, philosophy and critique - an introduction. Transmodernity 1(2), 115 .

Mateo-Babiano, I., 2016. Indigeneity of transport in developing cities. International Planning Studies 21, 132-147.

Mavhunga, C.C., Cuvelier, J., Pype, K., 2016. "Containers, carriers, vehicles": three views of mobility from Africa. Transfers 6(2), 43-53.

McKittrick, K., O’Shaughnessy, F.H., Witaszek, K., 2018. Rhythm, or on Sylvia Wynter's science of the word. American Quarterly 70(4), 867-874.

McKittrick, K., Wynter, S., 2015. Unparalleled catastrophe for our species? Or, to give humanness a different future: conversations, in: McKittrick, K., ed., Sylvia Wynter: On Being Human as Praxis, pp. 9-79. Duke University Press, Durham, NC.

Mennis, J., Mason, M.J., Cao, Y., 2013. Qualitative GIS and the visualization of narrative activity space data. International Journal for Geographical Information Science 27(2), 267-291.

Mignolo, W.D., 2011. The Darker Side of Western Modernity: Global Futures, Decolonial Options. Duke University Press, Durham, NC.

Miller, H.J., 1999. Measuring space-time accessibility benefits within transportation networks: basic theory and computational procedures. Geographical Analysis 31(1), 187212.

Minal, S., Ravi Sekar, C. 2016. Commuter's sensitivity in mode choice: An empirical study of New Delhi. Journal of Transport Geography 57, 207-217.

Norwood, M.,F., Lakhani, A., Maujean, A., et al., 2019. Brain activity, underlying mood and the environment: a systematic review. Journal of Environmental Psychology 65, 101321.

Notar, B., Min, K.S., Gautam, R., 2017. Echoes of colonial logic in re-ordering "public" streets from colonial Rangoon to postcolonial Yangon. Transfers 8(3), 55-73.

Parker, E.A., 2019. The human as double bind: Sylvia Wynter and the genre of "Man". Journal of Speculative Philosophy 32(3), 440-449.

Prytherch, D., 2018. Law, Engineering, and the American Right-of-Way: Imagining a More Just Street. Palgrave Macmillan, Cham. 
Purifoye, G., 2015. Nice-nastiness and other raced social interactions on public transport systems. City \& Community 15(3), 286-310.

Quijano, A., 2000. Coloniality of power and eurocentrism in Latin America. International Sociology 15(2), 215-232.

Recker, W.W., Golob, T.F., 1976. An attitudinal modal choice model. Transportation Research 10(5), 299-310.

Reed-Musson, E., 2017. Shadow mobilities: regulating migrant bicyclists in rural Ontario, Canada. Mobilities 13(3), 308-324.

Rekhviashvili, L., Sgibnev, W., 2018. Uber, marshrutkas and socially (dis-)embedded mobilities. Journal of Transport History 39(1), 72-91.

Rimmer, P.J., 1984. The role of paratransit in Southeast Asian cities. Singapore Journal of Tropical Geography 5(1), 45-62.

Rink, B., 2016. Race and the micropolitics of mobility: mobile authoethnography on a South African bus service. Transfers 6(1), 62-79.

Schalekamp, H., 2017. Lessons from building paratransit operators' capacity to be partners in Cape Town's public transport reform process. Transportation Research Part A: Policy and Practice 104, 58-66.

Schwanen, T., 2016. Geographies of transport I: reinventing a field? Progress in Human Geography 40(1), 126-137.

Schwanen, T., 2017. Geographies of transport II: Reconciling the general and the particular. Progress in Human Geography 41(3), 55-64.

Schwanen, T., Ettema, D., 2009. Coping with unreliable transportation when collecting children: Examining parents' behavior with cumulative prospect theory. Transportation Research Part A: Policy and Practice 43(5), 511-525.

Sgibnev, W., Vozyanov, A., 2016. Assemblages of mobility: the marshrutkas of Central Asia. Central Asian Survey 32(2), 276-291.

Seiler, C. (2016) Racing mobility, excavating modernity: a comment. Transfers 6(1), 98-102.

Sheller, M., 2003. Consuming the Caribbean: from Arawaks to Zombies. Routledge, London.

Sheller, M., 2009. The new Caribbean complexity: mobility systems, tourism and spatial rescaling. Singapore Journal of Tropical Geography 30(2), 189-203.

Sheller, M., 2018. Mobility Justice: The Politics of Movement in an Age of Extremes. Verso, London.

Shimazaki, T., Rahman, M., 1996. Physical characteristics of paratransit in developing countries of Asia. Journal of Advanced Transportation 30(2), 5-24. 
Souche-Le Corvec, S., Zhao, J., 2020. Transport and emotion: how neurosciences could open a new research field. Travel Behaviour and Society 20, 12-21.

Steg, L., 2005. Car use: lust and must. Instrumental, symbolic and affective motives for car use. Transportation Research Part A: Policy and Practice 39(2-3) 147-162.

Tang, I.-C., Tsai, Y.-P., Lin, Y.-B., et al. 2017. Using functional Magnetic Resonance Imaging (fMRI) to analyze brain region activity when viewing landscapes. Landscape and Urban Planning 192, 137-144.

Thrift, N., 2008. Non-representational Theory: Space, Politics, Affect. Routledge, Abingdon.

Timmermans, H., 1983. Non-compensatory decision rules and consumer spatial choice behavior: a test of predictive ability. The Professional Geographer 35(4), 449-455.

Valentine, G. (2010) Prejudice: rethinking geographies of oppression. Social \& Cultural Geography 11(6), 519-537.

Van, H.T., Choocharukul, K., Fujii, S., 2014. The effect of attitudes toward cars and public transportation on behavioral intention in commuting mode choice - a comparison across six Asian countries. Transportation Research Part A: Policy and Practice 69, 36-44.

Van Essen, M., Thomas, T., Chorus, C., et al., 2019. The effect of travel time information on day-to-day route choice behaviour: evidence from a real-world experiment.

Transportmetrica B: Transport Dynamics 7, 1719-1742.

Varela, H.R., Maturana, F.J., 1991. Autopoiesis and Cognition: The Realisation of the Living. D. Reidel Publishing Company, Dordrecht.

Verplanken, B., Aarts, H., Van Knippenberg, A., 1998. Habit, information acquisition, and the process of making travel mode choices. European Journal of Social Psychology 37(5), 539-560.

Walker, J.L., Li, J., 2007. Latent lifestyles preferences and household location decisions. Journal of Geographical Systems 9(1), 77-101.

Wang, D., Schwanen, T., Mao, Z., 2019. Does exposure to richer and poorer neighborhoods influence wellbeing? Cities 95: 102408.

Wang, Y., Chen, B.Y., Yuan, H., et al., 2018. Measuring temporal variation of location-based accessibility using space-time utility perspective. Journal of Transport Geography 73, 13 24.

Whitehead, A.N., 1920. Concept of Nature. Cambridge, MA: Cambridge University Press.

Woolf, S.E., Joubert, J.W., 2013. A people-centred view on paratransit in South Africa. Cities $35,284-293$.

Wynter, S., 1976. Ethno or socio poetics. Alcheringa 2(2), 78-94.

Wynter, S., 1984. The ceremony must be found: after humanism. boundary 2 12(3)/13(1), 1970. 
Wynter, S., 1989. Beyond the word of man: Glissant and the new discourse of the Antilles. World Literature Today 63(4), 637-648.

Wynter, S., 2003. Unsettling the coloniality of being/power/truth/freedom: towards the human, after Man, its overrepresentation - an argument. CR The New Centennial Review 3(3), 257-337.

Wynter, S., 2015. The ceremony found: towards the autopoietic turn/overturn, its autonomy of human agency and extraterritoriality of (self)-cognition, in: Ambrouse, J.R., Broeck, S. (eds.) Black Knowledges/Black Struggles: Essays in Critical Epistemology, pp. 184-245. Liverpool University Press, Liverpool.

Xiao, A.H., 2019. “Oyingo, Wole!”: urban rhythms and mobile encounters in the Lagos transport systems. Urban Forum 30, 151-171.

Zonn, L., 2020. “A place belongs forever”: Telling stories for the personal place project. GeoHumanities 6(1), 155-170.

Zorrilla, M.C., Hodgson. F. Jopson, A. 2019. Exploring the influence of attitudes, social comparison and image and prestige among non-cyclists to predict intention to cycle in Mexico City. Transportation Research Part A: Policy and Practice 60, 327-342. 
Table 1: Wynter's historical sequence of autopoietic systems generating different versions of the human subject in Western Europe

\begin{tabular}{|c|c|c|c|c|c|c|c|}
\hline Mode of being & $\begin{array}{l}\text { Symbolic } \\
\text { Death }\end{array}$ & Symbolic Life & $\begin{array}{c}\text { Spatiality of } \\
\text { non-normalcy } \\
\text { (Us/Them) }\end{array}$ & $\begin{array}{l}\text { Higher-level } \\
\text { force }\end{array}$ & $\begin{array}{c}\text { Era of } \\
\text { dominance }\end{array}$ & $\begin{array}{l}\text { Political } \\
\text { economy }\end{array}$ & Knowledge \\
\hline $\begin{array}{c}\text { Theological } \\
\text { (homo } \\
\text { religiosus) }\end{array}$ & $\begin{array}{l}\text { Original Sin; } \\
\text { layperson }\end{array}$ & $\begin{array}{l}\text { Redemption } \\
\text { through } \\
\text { baptism; } \\
\text { ecclesial } \\
\text { celibacy }\end{array}$ & $\begin{array}{l}\text { Mapped onto } \\
\text { the cosmos: } \\
\text { earth/heaven }\end{array}$ & $\begin{array}{l}\text { God, divine } \\
\text { causality }\end{array}$ & Middle Ages & $\begin{array}{c}\text { Medieval/ } \\
\text { ecclesial society }\end{array}$ & $\begin{array}{l}\text { Scholastic } \\
\text { knowledge }\end{array}$ \\
\hline $\begin{array}{c}\text { Man1 } \\
\text { (homo politicus) }\end{array}$ & $\begin{array}{l}\text { Irrationality; } \\
\text { emotion, } \\
\text { value, myth; } \\
\text { madness }\end{array}$ & $\begin{array}{l}\text { Obtaining } \\
\text { rational } \\
\text { knowledge, } \\
\text { facts }\end{array}$ & $\begin{array}{l}\text { Follows } \\
\text { colonialism: } \\
\text { phenotype, } \\
\text { religion \& } \\
\text { culture }\end{array}$ & $\begin{array}{l}\text { Nature, natural } \\
\text { causality }\end{array}$ & $\begin{array}{l}\text { Renaissance- } \\
18^{\text {th }} \text { century }\end{array}$ & $\begin{array}{l}\text { Monarchical } \\
\text { state, colonial } \\
\text { exploration, rise } \\
\text { of landed gentry }\end{array}$ & $\begin{array}{c}\text { Exact } \\
\text { sciences }\end{array}$ \\
\hline $\begin{array}{c}\text { Man2 } \\
\text { (homo } \\
\text { economicus) }\end{array}$ & $\begin{array}{c}\text { natural } \\
\text { scarcity; } \\
\text { genetic/racial } \\
\text { de-selection }\end{array}$ & $\begin{array}{l}\text { Rational } \\
\text { allocation; } \\
\text { genetic/racial } \\
\text { selection }\end{array}$ & $\begin{array}{l}\text { Premised on } \\
\text { Colour Line \& } \\
\text { socioeconomic } \\
\text { difference }\end{array}$ & Evolution & $\begin{array}{c}\text { Since late } \\
18^{\text {th }} / \text { early } 19^{\text {th }} \\
\text { century }\end{array}$ & $\begin{array}{l}\text { Modern nation- } \\
\text { state, } \\
\text { Industrialisation, } \\
\text { imperialism, rise } \\
\text { of Western } \\
\text { bourgeoisie }\end{array}$ & $\begin{array}{c}\text { Biological \& } \\
\text { economic } \\
\text { sciences }\end{array}$ \\
\hline
\end{tabular}


Table 2: Selected studies employing the Theory of Planned Behaviour

\begin{tabular}{|c|c|c|c|c|c|c|}
\hline \multirow[b]{2}{*}{ Study } & \multirow{2}{*}{$\begin{array}{l}\text { Geographical } \\
\text { location }\end{array}$} & \multirow[b]{2}{*}{ Sample } & \multirow[b]{2}{*}{ Dependent variable } & \multicolumn{3}{|c|}{ Measurement items } \\
\hline & & & & $\begin{array}{l}\text { Tech- } \\
\text { nique }\end{array}$ & $\begin{array}{l}\text { Selected items linked to } \\
\text { 'symbolic life' }\end{array}$ & $\begin{array}{l}\text { Items associated linked to } \\
\text { 'symbolic death' }\end{array}$ \\
\hline $\begin{array}{l}\text { Van et al. } \\
(2014)\end{array}$ & $\begin{array}{l}\text { - Bandung, } \\
\text { Indonesia } \\
\text { - Bangkok, } \\
\text { Thailand } \\
\text { - Ho Chi Minh, } \\
\text { Vietnam } \\
\text { - Metro Manila, } \\
\text { Philippines } \\
\text { - Tianjin, China } \\
\text { - Tokyo, Japan }\end{array}$ & $\begin{array}{l}1118 \text { first-year } \\
\text { engineering } \\
\text { students at } \\
\text { university; } \\
\text { convenience } \\
\text { sample }\end{array}$ & $\begin{array}{l}\text { Intention to use one of } \\
\text { three modes for work } \\
\text { travel after getting a } \\
\text { job: car, public transit, } \\
\text { or other modes }\end{array}$ & $\begin{array}{l}\text { Five-point } \\
\text { bipolar } \\
\text { adjective } \\
\text { scale }\end{array}$ & $\begin{array}{r}\text { - Rich-F } \\
\text { - Cheap-Ex } \\
\text { - Aristocrati } \\
\text { - Advanced-T } \\
\text { - Fashionable } \\
\text { - Controllable-U } \\
\text { - Free-No }\end{array}$ & $\begin{array}{l}\text { oor } \\
\text { pensive } \\
\text {-Vulgar } \\
\text { raditional } \\
\text { Outdated } \\
\text { controllable } \\
\text { t free }\end{array}$ \\
\hline $\begin{array}{l}\text { Loo et al. } \\
(2015)\end{array}$ & $\begin{array}{l}\text { Johor Bahru, } \\
\text { Malaysia }\end{array}$ & $\begin{array}{l}488 \text { commuters } \\
\text { from Johor } \\
\text { Bahru into } \\
\text { Singapore; } \\
\text { stratified } \\
\text { random sample }\end{array}$ & $\begin{array}{l}\text { - Affective motives } \\
\text { (car) } \\
\text { - Instrumental motives } \\
\text { (car) } \\
\text { - Symbolic motives } \\
\text { (car) } \\
\text { - Affective motives } \\
\text { (PT)Instrumental } \\
\text { motivates (PT) } \\
\text { - Symbolic motives } \\
\text { (PT) }\end{array}$ & $\begin{array}{l}\text { Five-point } \\
\text { Likert } \\
\text { scale }\end{array}$ & $\begin{array}{l}\text { - To me, driving a car is a great } \\
\text { pleasure } \\
\text { - I feel free and independent when I } \\
\text { drive } \\
\text { - Driving is more convenient and } \\
\text { flexible } \\
\text { - Driving is cheaper than other } \\
\text { modes } \\
\text { - Driving/owning a car gives me } \\
\text { more prestige and status than } \\
\text { someone who takes public } \\
\text { transport }\end{array}$ & $\mathrm{n} / \mathrm{a}$ \\
\hline $\begin{array}{l}\text { Acheampong } \\
\text { (2017) }\end{array}$ & Kumasi, Ghana & $\begin{array}{l}500 \text { adults; } \\
\text { random sample } \\
\text { in } 4 \text { communi- } \\
\text { ties within } \\
\text { Kumasi }\end{array}$ & $\begin{array}{l}\text { Intention to cycle to } \\
\text { work }\end{array}$ & $\begin{array}{l}\text { Five-point } \\
\text { Likert } \\
\text { scale }\end{array}$ & $\begin{array}{l}\text { - Cycling to work would be fun } \\
\text { - Cycling to work would be fast } \\
\text { - Cycling to work would make me } \\
\text { healthy } \\
\text { - If I wanted, I could cycle to work }\end{array}$ & $\begin{array}{l}\text { - Other people will think I } \\
\text { am poor if I cycle to work }\end{array}$ \\
\hline
\end{tabular}

Continues on next page 


\begin{tabular}{|c|c|c|c|c|c|c|}
\hline $\begin{array}{l}\text { Belgiawan } \\
\text { et al. (2017) }\end{array}$ & $\begin{array}{l}\text { - Beirut, Lebanon } \\
\text { - Berkeley, USA } \\
\text { - Indonesia } \\
\text { - China } \\
\text { - Taiwan } \\
\text { - Utrecht, NL }\end{array}$ & $\begin{array}{l}1229 \\
\text { university } \\
\text { students; } \\
\text { different } \\
\text { sampling } \\
\text { methods }\end{array}$ & $\begin{array}{l}\text { Intention to purchase a } \\
\text { car }\end{array}$ & $\begin{array}{l}\text { Five-point } \\
\text { Likert } \\
\text { scale }\end{array}$ & $\begin{array}{l}\text { - Cars are cool } \\
\text { - Cars bring prestige } \\
\text { - Cars allow to distinguish oneself } \\
\text { from others } \\
\text { - Cars allow one to be independent } \\
\text { - Cars allow one to travel anywhere }\end{array}$ & $\mathrm{n} / \mathrm{a}$ \\
\hline $\begin{array}{l}\text { Zorilla et al. } \\
(2019)\end{array}$ & Mexico City & $\begin{array}{l}401 \text { adults, } \\
\text { convenience } \\
\text { sample }\end{array}$ & $\begin{array}{l}\text { Intention to use cycling } \\
\text { for commuting }\end{array}$ & $\begin{array}{l}\text { Five-point } \\
\text { Likert } \\
\text { scale; } \\
\text { five-point } \\
\text { bipolar } \\
\text { adjective } \\
\text { scale }\end{array}$ & $\begin{array}{l}\text { - Riding my bicycle gives me } \\
\text { freedom and independence } \\
\text { - The better your bike is, the more } \\
\text { successful you are in life } \\
\text { For an individual that daily covers } \\
\text { to choose use the bicyc } \\
\text { Beneficial-H } \\
\text { Enjoyable-Une } \\
\text { Good-B }\end{array}$ & $\begin{array}{l}\text { - If I commute by bicycle I } \\
\text { often feel that other people } \\
\text { would think that I am poor } \\
\text { a distance of less than } 8 \mathrm{~km} \text {, } \\
\text { le to commute is: } \\
\text { armful } \\
\text { njoyable } \\
\text { ad }\end{array}$ \\
\hline
\end{tabular}

